\title{
The Stories They Carried: Reflections of Vietnamese-Canadians 40 Years after That War
}

\author{
PRISCILLA $\mathrm{KOH}$
}

\begin{abstract}
This article explores the narratives of former refugees from Vietnam who resettled in Canada. Each of these stories highlights the profound dilemmas, motivations, and experiences of Vietnamese refugees. Collectively, they demonstrate the remarkable resilience of this community, and their determination to survive and remake themselves in Canada. The discussion illuminates the diversity and complexity of my respondents' senses of belonging, homes, and homelands, and how such notions and ties are continually evolving. The research aims to contribute to the postwarl refugee discourse, and to move the field beyond the parameter of the war and exodus from Vietnam, in order to study Vietnamese in all their complexities-in a new locale.
\end{abstract}

\section{Résumé}

Cet article explore les discours des anciens réfugiés du Vietnam qui se sont réinstallés au Canada. Chacune de ces histoires souligne les dilemmes profonds, les motivations et les expériences des réfugiés vietnamiens. Collectivement, elles démontrent la capacité remarquable d'adaptation de cette communauté, et leur détermination de survivre et de se réinventer au Canada. La discussion met en lumière la diversité ainsi que la complexité des sentiments d'appartenance, de domicile, de patries, chez mes répondants, et comment ces notions et ces liens sont en processus continuel d'évolution. Cette recherche a pour but de contribuer sur le discours de l'après-guerre et des réfugiés, et de faire évoluer le domaine au-delà des paramètres de la guerre et de l'exode du Vietnam, afin de pouvoir étudier les Vietnamiens dans toute leur complexité, dans le contexte d'un nouvel environnement.

Ah, the stories we tell and the stories told to us.

- Caroline $\mathrm{Vu}^{1}$

$\mathrm{M}$ emories of the boat journey still trigger strong emotions within the diasporic community decades after their departure from Vietnam. Forty years after that war, stories about the boat journey continue to be told and retold through memoirs, academic research, films, television, and radio programs. ${ }^{2}$ The narratives of six Vietnamese-Canadians highlighted in this article show not just the diversity of the "boat people's" experiences, but also its complexity and deeply personal aspects. The first section provides a brief historical overview of Vietnam's refugee crisis. The following sections explore different facets of my respondents' "boat journeys": their reasons for leaving Vietnam, their departures from Vietnam and experiences at refugee camps in Southeast Asia, and the challenges of adapting to their new lives in Canada. Finally, the discussion will examine their current perspectives of and ties with Vietnam.

\section{Respondents and Methodology}

In-depth life-story interviews were conducted in Ottawa between October 2014 and April 2015. Through the snowballing method, I was able to meet and become acquainted with my respondents. To capture the diversity of "boat 
experiences," I sought and selected individuals who had different motivations for leaving the country and espoused varying cultural outlooks and perspectives about Vietnam. My respondents originated from different regions in Vietnam; all live in Ottawa except for one, who is based in Toronto. They range in age from the mid-40s to 6os; all are universityeducated and white-collar professionals. Three have made several return trips to Vietnam over the past two decades, whilst the rest have not been back since they fled the country.

The interviews were conducted primarily in Vietnamese, since it is the language my respondents felt most comfortable with. The interviews ranged from an hour to three hours long each time, typically taking place in cafes and restaurants in the Chinatown area of Ottawa, and in the case of one respondent in a home. ${ }^{3}$ These venues were not only the most convenient and easily accessible for my respondents, but were also spaces they were familiar with and felt comfortable in. The interview questions were semistructured and open-ended. They sought to cover the major life domains associated with their refugee experience: experiences growing up in Vietnam, motivations for leaving the country and sense of "home" since their resettlement in Canada. 4

The narratives presented here are not intended to encapsulate the full spectrum of the sentiments and experiences of Vietnamese Canadians, or for that matter, the Vietnamese refugee diaspora. That is beyond the scope and resources available for this project. The purpose of this research is to describe these emergent themes and what they suggest about the notions of home and belonging for first-generation Vietnamese refugees. As a case study, researching Canada's Vietnamese refugee narratives is useful in understanding other diasporic groups in the country who have followed similar trajectories. Their myriad departure and resettlement experiences can teach lessons about cultural change, the construction of communities, and the evolving meanings of identity, home, and culture. These narratives also shed light on the various forms that national membership and belonging can take shape.

\section{Vietnam's "Boat People": A Brief Historical Overview}

The second Indochina conflict (1954-1975) resulted in the largest mass exodus of Vietnamese overseas. In the years following the end of the conflict and national reunification, more than one million former soldiers, civil servants, and teachers were subjected to học tập cải tạo (re-education), equivalent to a form of imprisonment whereby detainees were subject to years of intense political indoctrination and gruelling labour in secluded camps. Another million were forcibly de-urbanised and relocated to the khu kinh tể mới
(New Economic Zones) located in inhabited mountainous areas. 5 As a result of the deprivations of the postwar period, it has been estimated that between 1.4 and 1.5 million Vietnamese fled the country between 1975 and $1990 .^{6}$

Between the mid-1970s and the 1990s, Vietnamese left the country in three distinct waves. The first wave in 1975 included 140,000 southern Vietnamese, mostly political leaders, army officers, and skilled professionals escaping the communist takeover. In the second wave (1978-81), close to 400,000 refugees fled Vietnam. Due to the fact that many of these refugees typically fled the country onboard overcrowded and dangerously constructed boats, the popular misnomer "boat people" became the new term of reference for all Vietnamese refugees. Ethnic Chinese made up 70 per cent of the boat people. The third wave left Vietnam as part of the Orderly Departure Program (ODP).7 By the mid1990s, over 200,000 Vietnamese had entered the United States through the oDP. ${ }^{8}$ Each wave faced complex contexts of exits and resettlement that affected family dynamics and adaptation. ${ }^{9}$ By the end of the 1990s, the vast majority of Vietnamese refugees were eventually resettled in the United States. Others found home in far-flung countries, including Australia, Canada, China, France, Great Britain, and Germany. ${ }^{10}$

\section{Life after the Fall of Saigon}

My respondents reflected how both their family and personal lives were affected by the change of political regime. Life for them had not changed drastically in the immediate period following communist victory over South Vietnam in 1975 . By the late 1970s, however, they would witness drastic changes in their daily lives as the regime embarked on aggressive socialization campaigns throughout central and southern Vietnam.

Dung was born in Hanoi in 1952. Her family fled to Saigon after 1954 for political and religious reasons; ${ }^{11}$ they were Buddhists who detested and feared communist rule. Dung's family lived in Saigon's Phu Nhuan district. She recalled how, after reunification, the communist soldiers moved into her family home and stayed there for a year. Dung found their mannerisms and lifestyle strange and shocking at the time: "I remember how dishevelled and malnourished these young men looked when they first arrived at our doorstep. They were out of touch with modernity and urban living, having fought and lived in the jungles for so many years. They didn't know how to use a stove and almost burnt our house down a couple of times. They were also unfamiliar with modern sanitation; the flush toilet was a shocking discovery for them. They used the toilet bowl to wash their clothes. We were completely flabbergasted when they took our family dog to cook and eat!"12 
Like Dung, Phuong's family had to share their home in Danang, central Vietnam, with the victorious soldiers, who eventually took possession of the house. Then, he recalled feeling sympathetic towards the soldiers, whom he described as a "raggedy and starved band of men who had sacrificed their youth, and were willing to risk their lives for the sake of unifying the country."13 During the first round of the regime's socialization campaign, the family business in the sale of imported bike parts was targeted, and the shop was confiscated. Unlike the rest of his family, who were resentful and wary of communist rule, Phuong said he actually felt glad when the communists took over the South. He had always yearned for a single, unified country that was free from war since his childhood. This was a viewpoint that raised the ire of the rest of his family, who were vehemently opposed to communist rule.

By contrast, the experiences of the Le family in Quy Nhon, central Vietnam, were much more dramatic and distressing. Sisters Mai and Chi recounted how their father was arrested shortly after the communist takeover. He had been a manager of the us embassy compound in Quy Nhon. After 18 months in jail, their mother managed to secure a conditional release of their father by bribing the officials in charge of his case; Mr. Le was to serve the rest of his sentence under house arrest. However, this reprieve was short-lived. In 1978, armed police stormed the family house. Chi recalled, "The police tore apart every room in the house, searching for evidence to incriminate my father. They went through each page of our school books, emptied the cupboards, spilled bags of rice onto the floor. They rearrested him, even though they didn't find anything, this time sentencing him to 18 years behind bars in the notorious Xuan Phuoc re-education camp."14

During those years, their mother supported her seven children with earnings from her shop in the market. Phuong Mai recalled how their mother was adamant that the children's every need be met and that they should always be well-clothed and fed. "My mother wanted life to carry on as it was before our father went to prison, before the communists took over. Whenever we visited Dad, she would make sure we were dressed to the nines. It was as if it was Tet [the Vietnamese lunar new year] all over again! We also learnt never to say the word thèm [crave] to her, because she would go out and buy large quantities of whatever we craved! More than to assure my father, I think she really wanted to convince herself that we were all doing fine."15

Likewise, Nhung and her family were determined to ride out the uncertain times during the early years after the war. She recalled how she had both the opportunity and means to leave in 1975 , but did not:
There were many reasons that made it difficult for me to leave ... the main one was the belief that a third, middle ground forcethat was neither communist or southern republic-would emerge and eventually take over the country. But mặt trận dân tộc giải phóng miên nam Việt Nam [National Liberation Front of South Vietnam], which we had believed was the third force, turned out to be a Việt Cộng organization after all.

I also didn't want to leave my parents in Vietnam. Even though I wanted to study overseas and had the opportunity to leave then, I decided to stay on to be with my parents. When it came time for me to resume my studies, I moved to Saigon to attend university there. I was reluctant to leave Danang at first, but my mother was adamant that I move to Saigon for my studies, since it had better educational prospects. ${ }^{16}$

The narratives reveal that my respondents chose to remain in Vietnam for various reasons. Mostly, they were reluctant to leave their families and loved ones behind. Then, there was also the hope and belief that things would not get worse. They would be proven wrong in this regard.

\section{The Epiphany: The Impetus to Leave}

In the early period following national reunification, Nhung recalled the initial optimism she about the new leadership. Like many youth then, she had "positive hope" that communist ideology and leadership would bring about peace, unity, social order, and equality in the country after decades of war. But this optimism vanished after she moved to Tay Son, a mountainous region in central Vietnam, to work as a teacher.

I taught English as a second language at a local school. Malaria was widespread in this area and many students and staff got sick. I learned that the communist dictum "One for All and All for One" was a scam. The new system was one in which only a minority of the high-ranking officials benefitted [cán bộ có ưu tiên]. The majority of the population were impoverished. People had neither enough food nor access to medical care and education. I saw how morally corrupt and inept the new regime was. The black market was rife. People took advantage of helpless or desperate people to profit from the ration coupon system. The new system brought out the worst in people.

Worst of all, we had no right to complain ... I could hardly feed myself with my salary and had to keep my mouth shut when I saw anything wrong with the regime. My mother worried that someday I would burst out and be arrested for my "reactionary" thoughts and actions. ${ }^{17}$

Nhung knew she could not stay in Vietnam. Neither could her brother. He had been drafted to serve in the army a year earlier and her mother had bribed a high-ranking 
communist official to get him out. However, he was still not safe, as he could be drafted at any time to fight in Cambodia. That was when her parents started to make plans for Nhung and her brother to leave the country.

Like Nhung, Dung's realization that she had little or no future in postwar Vietnam was made increasingly apparent in the postwar years. Politically and socially, she was considered "undesirable" and "problematic" under both regimes, because of her English skills and religious background. Under the old regime, she had been thrown in prison twice (in 1970 and 1972) for taking part in anti-war protests. Her actions led the Southern regime to label her a communist. Dung was also not trusted by the new regime because of her English language skills and considerable social network with Westerners in Saigon; they were suspicious of her, thinking that she might be a spy for the CIA. Under communist rule, religious groups were hit hard. During 1978-9, Buddhist monks had to disrobe, become civilians, and avow atheism in order to survive. Dung recalled how daily life got worse for Vietnamese people from 1976 to 1979: "No one was able to find work, because there was no work available. There was little or no health care available for civilians; hospitals were usually reserved for party officials. And there were no more foreign books, which I loved to read. Like Doctor Zhivago, which was one of my favourite novels in my youth." 18

Mai and Chi's family were also determined to ride out the difficult times of the postwar period, believing things could not get worse than they already were. The turning point for them was when their parents learnt that their children would not be able to pursue higher education in Vietnam, being offspring of those who had worked with the "enemy." Of immediate concern was the likely prospect that their eldest son and daughter would be drafted into military service or sent to work in remote state farms respectively. It became increasingly apparent to them that their family had no future in Vietnam, and that if they were to survive, they had to escape. Their eldest son and his uncle were the first to leave in 1978. They were eventually sponsored to Canada in 1980. Chi and Mai, then 15 and 12 years of age respectively, were next in line. Chi emphasized how difficult it was for her mother: "People underestimate how difficult it was for parents to send their children off on the boat, to split up the family like that. No, they were not cold, calculating parents who took this decision lightly. It broke my mother's heart to have to do this. But that was the only way for us, for the family to survive. And she had to make very tough decisions. I was so mad with my mum in the period before I left, I thought she didn't want me around to help her anymore. But now that I am a mother myself, I can understand the pain she must have gone through."19
A close family friend later told her how her mother cried after sending her two daughters off in the boat. People in the market recognized that it was such a sacrifice for her mother to send her eldest daughter, likening the decision to that of cutting or losing your right arm. Chi was her mum's right arm-helping with the business and the home.

\section{Leaving Vietnam: The Boat Journey}

For Nhung, her family's first attempt to escape in 1979 failed; they had been cheated by fake organizers and boat masters. They lost so much money after several failed attempts that her father, in despair, once considered committing suicide. Finally, her parents decided that with the gold they had left, they would send only Nhung and her brother. If the siblings were arrested, they would bribe them out of prison and make another attempt. In July 1980, Nhung left Danang with her brother, on a small boat with 41 people and a dog. She recalled that the boat master was young, inexperienced, and clueless about boats. ${ }^{20}$ After five days at sea, they encountered two typhoons. During the second typhoon, Nhung thought they would die. ${ }^{21}$

The Le sisters encountered horrific storms on their boat journey out of Vietnam as well. With their eldest brother and uncle in Canada, it was time for Chi, as the eldest daughter, to leave also. By then, however, security was much tighter and it became much harder to escape. Chi estimates that she had made twenty attempts to escape: four times she had gotten lost; the other times the assigned boat did not turn up. During the second-last attempt, the vessel she was travelling on was discovered by local authorities; Chi was thrown in jail for two months. In 1981, in her final attempt, Chi left on a boat purchased by her mother, together with her younger brother Minh, Mai, and a young cousin. She recalled,

The boat sailed to a fishing village off the coast of Quy Nhon, and then it ran out of fuel. The two young men manning the boat tried to steal fuel from fishing boats in the area. They were desperate and had no weapons whatsoever, so the two men covered a wooden stick with a cloth, and tried to pass it off as a rifle, instructing passengers to light a fire cracker each time they "fired." It was a pathetic and laughable ruse, because we could see the wooden stick protruding from under the cloth at times! However, the two men, who were native to this region, were immediately recognized by those they were trying to rob. The villagers asked them why they were doing this, when they would have gladly helped the men had they been asked in the first place. The villagers not only gave us fuel, but also food, and told us the best places to hide in the vicinity to avoid detection. ${ }^{22}$

The crew sailed on to Macau. Along the way, the craft was hit by three storms. In one particularly horrendous 
one, the waves sent the boat flying up, suspended in mid-air, and then crashing down each time. Chi and Mai recalled being terrified. The boat eventually drifted onto the coast of Macau. They recalled the locals as kind and friendly folk who pointed them in the direction of Hong Kong. When they reached Hong Kong, they had to dock for one week for quarantine.

By comparison, the boat journeys for the others were relatively uneventful. The ease in leaving the country during the late 1970 s was aided by the regime's ostensible policy to "facilitate" the departure of its Chinese residents. There was brazen official endorsement, encouragement, and collusion to expedite the outflow of Chinese-Vietnamese. Profiteering and racketeering were rampant among officials. ${ }^{23}$ Many ethnic Vietnamese seeking to escape bought Chinese papers to facilitate their departure. Khue's mother bought Chinese identification papers and tickets for Khue and his brothers on a big ship, which was intended for ethnic Chinese-Vietnamese leaving the country. The normal fare was between six and seven taels of gold, but because theirs was an emergency sale, the cost doubled. Their mother took them to the ship in the coastal city of Vung Tau in the middle of the night, instructing them not to speak Vietnamese under any circumstance, and only to say their fake "Chinese name" when asked about their identities.

The ship was huge. It was empty at first. I even had a room to myself. I felt excited. It was like I was going on a vacation! After two days, the ship filled up with 1,500 people. As the ship went up along the coast, I could still see Vietnam. Even though I was no longer there, Vietnam was never far from me. At one point of the journey, I could even hear bombing and shouting along the border with China. It was strangely comforting and yet sad, to be so close and yet so far from my homeland, and to hear the conflict still going on while I was escaping. I could hear shooting and shouting along the coast. ${ }^{24}$

The ship ended up on a small island off Hainan, China's southernmost province. There the Chinese coast guard let them in. The villagers sold food to the refugees and fixed their damaged ship for a fee. They would spend about a month on the island before departing for Hong Kong. However, they learnt that another bigger ship attempting to enter Hong Kong had been stopped and turned around by the coast guard. The vessel then proceeded to an island close to Macau, whose authorities eventually sent them to Hong Kong. There, they would spend about three months at the Whitehead detention centre.

Like Khue, Phuong's family bought Chinese papers for him and his brother, paying about 10 taels of gold per passenger. Phuong said he was sad to leave Vietnam and did not want to leave the country, because he had a high school sweetheart in Saigon. However, his parents were adamant that the whole family had to leave and quickly made arrangements to do so. In December 1979, the brothers left from Soc Trang, southern Vietnam. Phuong recalled being escorted by the local police boat out of the country that night; they followed their vessel all the way out and even bid them farewell before turning back. Phuong's parents and the rest of the family were the last to leave. They all ended up in different camps and would lose contact with each other for the next few years. Most of his family were resettled in Belgium. Phuong recalls, "The boat was really a fishing boat, packed with about 228 people. It sailed for three days. It seemed like we were heading to the middle of nowhere. Then, there was a big storm. I really thought that we were all going to drown then. When we reached the Malaysian coast, our boat masters deliberately sank the boat so that the coast guard would have no choice but to rescue them and let them on the island. They must have heard about the experiences of others who had unsuccessfully tried to land in Malaysia."25

In early 1981, Dung departed from Ca Mau, a city in southern Vietnam, in the wee hours of the morning. To avoid raising suspicion, the passengers were instructed not to bring anything for the journey. If they got caught, they were to say that they were not escaping but "catching fish." She recounted how some relatives had been caught earlier, and the police found lots of personal effects on them that indicated they were leaving the country. They were thrown in prison for months.

Along the way, the boat they were travelling on was attacked by Thai pirates. Dung recalled the pirates as young and somewhat inexperienced. There was not much they could steal from the passengers, since they did not have much to begin with. The pirates ended up taking diesel and some other small items from the boat. They seemed to relent when they saw a picture of Buddha on the boat, and returned the items to the passengers. Dung guessed that their assailants might have been Buddhists themselves, and felt guilty about robbing them. The one aspect of the boat journey that remained vivid and entrenched in her memory after all these years was the "strong and unbearable" smell of diesel (mùi xăng) in her hair. When the pirates ransacked the boat, they knocked over the barrel of diesel, which leaked onto the passengers hiding below the deck. For the rest of the journey, Dung had diesel all over her hair. She longed to wash it but could not. During those days, she thought that she was truly going crazy and was afraid that she was not going to make it to the next destination alive.

The boat eventually reached the coast of Pulau Bidong, off Terengganu in Malaysia. It circled the island for about four 
nights and five days. The crew and passengers had lost sense of time and geography, and some actually believed that they were still close to Nha Trang, in central Vietnam. Fortunately for them, by the 1980s, UNHCR had made an agreement with the Malaysian authorities, allowing refugees to enter the camps. The locals along the coast shouted and waved at them, pointing them in the direction of Terengganu. Dung recalled the Malay folk along the shore throwing cigarettes towards their craft, asking them to smoke and gesturing to them that they were safe now. ${ }^{26}$

\section{Life in the Camp}

For refugees, the conditions and quality of life in the camps varied according to their location; different camps had different policies, resources, and arrangements with the UNHCR and local authorities. Hong Kong had the largest and most organized camp structures. Camp conditions in Pulau Bidong, in Malaysia, on the other hand, were rudimentary.

Upon reaching the shores of Hong Kong, Nhung and the other passengers were escorted by the Hong Kong Royal Marine Police to a big dock, where they were quarantined for a week. After they were allowed to land, they were placed in a prison for another week while the Hong Kong immigration officers and UNHCR processed their paperwork. They were then released to an open camp where they could work outside of the camp while awaiting resettlement. There, Nhung worked as an interpreter for the Red Cross clinic. "There, I saw many things that I had never before seen: victims of spousal and child abuse, robbery, orphans whose mother was murdered the night before, abortion, the birth of twins, death, so many types of diseases."27 Nhung stayed in Hong Kong for six months before being sponsored for resettlement in Canada.

Chi and Mai's stay in Hong Kong was also brief. After the initial quarantine, they were moved to Jubilee camp (the first in a three-tiered camp structure). After a month, they were able to move to Kai Tak camp, where refugees had significantly more freedom of movement. There, refugees were able to leave the camp on day passes for work. Coming from a sheltered upbringing in Vietnam, camp life shocked Chi and Mai: robberies, rapes, and murders were not uncommon. For Mai, however, the hardest thing for her was seeing people live out most of their lives at the camp: getting married and raising a family there, playing what seemed like an eternal waiting game to be accepted for resettlement.

At Kai Tak camp, the sisters said they were fortunate to have met a middle-aged Vietnamese couple, who took care of and watched out from them, treating the teenagers as their own children. Chi and Mai say they are grateful for the kindness shown to them and will never forget these two people, although they did not keep in touch after leaving the camp.
After a few months, they were transferred to Argyle, the final-stage camp before being allowed to leave the country. They stayed in Hong Kong for four months before leaving for Toronto in January 1982. The Le sisters were sponsored by their uncle and elder brother who were already there. ${ }^{28}$

Camp conditions in Malaysia were generally rudimentary and unsanitary. At Shillington camp on Pulau Bidong, Phuong recalled that living conditions were terrible: "There was no sanitation at the camp. Food was sponsored by the Red Cross. There were no trees at the camp, which faced the ocean. It was like a real concentration camp, surrounded by barbed wire." 29 He said he was thankful that he was able to put some of the knowledge and skills he had picked up as a Boy Scout in his youth to use during his stay at the camp, such as cooking, and pitching tents. Dung's recollection of camp life were similar; she recalled how there were rats and cockroaches everywhere, and food-borne and infectious diseases were rife. During her time at Bidong, she suffered from dysentery for weeks. She also had head lice and had to put diesel on her hair to kill the lice. To pass time at the camp, Dung worked as a translator, helping with the medical and dental checkups for the refugees..$^{30}$

\section{Coming to Canada}

Between 1979 and 1981, Canada accepted 60,00o Vietnamese refugees. Those who arrived during this period described a relatively easy and quick resettlement. By 1985, 110,00o Vietnamese refugees had settled in Canada. ${ }^{31}$ Nhung received approval to come to Canada in December 1979. She arrived in early January 1980.32 Although the United States was a viable option for Nhung's family, because her father was a former employee of the South Vietnam administration, and they were eligible to move there under the oDP program, Nhung chose Canada for pragmatic and personal reasons. It was easy for her to come to Canada and eventually sponsor her family. Furthermore, her experiences growing up near the us military base in Danang left her with a distaste for American culture and negative associations with the war:

Most of my fellow boat people went to the United States, but I preferred to come to Canada. I was still haunted by the war and did not want to be reminded of it. Also, the behaviour of the American soldiers did not leave me with a good impression of American culture; they were boisterous, noisy, and did not seem very intelligent! Canada struck me as a peaceful country. I was impressed by the simplicity and elegance of the Canadian flag: there was no star, no sun, no moon, and no stripes. There was just a leaf. How modest and how nice. ${ }^{33}$

Arriving in Ottawa with her brother in early 1981, Nhung saw snow for the first time and experienced how cold it 
could get in Canada. She described the first few years of life in Canada as tough. She could not sleep well for the first two years and had continual nightmares of her boat journey: the typhoons, being thrown around on the seas, and waking up afraid. In the early days of her resettlement, Nhung not only felt like a fish out of water, but was also ridden by a profound sense of guilt:

Back then, the Vietnamese community was very small. There were no Vietnamese restaurants in Ottawa and only one Vietnamese grocery store. I did not know many people. For the first few years after I arrived in Canada, I was homesick and plagued by guilt. The letters from Vietnam were deeply distressing. Our family had been labelled "traitors" and the Vietnamese government did not allow the "traitors" relatives to leave the country under the "traitors" sponsorship. My mother frequently wrote about her fear of never seeing us again. Relatives and friends would write about how their families were starving or gravely ill, asking us to send money home to them. I lived in guilt and could not eat well. I thought that I had no right to enjoy good food in Canada if my people in Vietnam were starving. So I ate just to live. ${ }^{34}$

During the first year, she worked at the assembly lines of Digipix System, a digital satellite imaging company. Soon after, she enrolled at the University of Ottawa, studying sociology, while working part-time at the National Library. Upon graduating, Nhung went to law school for an additional four years. She became a lawyer in March 1990, opening a law practice the same year. In July 1991, she went on a fact-finding trip to Southeast Asia refugee camps, including Hong Kong for a month. Then, Nhung felt proud to be able to return as a lawyer helping others, not as a refugee.

Like Nhung, Khue had a fairly quick and easy process coming into Canada. He and his brothers arrived in Montreal in August 1979, moving to Toronto shortly after. Adjusting to life in Canada, however, proved to be an insurmountable challenge for Khue. After graduating from high school, Khue moved to Ottawa, where he studied engineering at Carleton University. He quit his studies at the age of 25, after struggling with classes and projects. Khue traced the start of his depression to this period. It was also then that he sponsored his parents to come to Canada. He felt a deep sense of shame at his lack of academic success and found it hard to face his family. Khue moved to Montreal shortly after his parents came to Canada. There, he washed dishes to get by and went on welfare for the next three years. Khue described himself as a "lost guy" during this period.

Eventually, Khue moved back to Ottawa and enrolled in an accounting course at Algonquin College. After he got his degree, he felt like a "normal" person and regained his pride. For the next two decades, Khue worked in a series of jobs-accounting, administration, and real estate-but could not find meaning and satisfaction. Then his health broke down. Eight years ago, Khue developed kidney failure. He now lives in Toronto, close to his family, and has been on dialysis for six years. He is at the top of the wait list for a kidney transplant.

Khue reflects that his illness was a turning point in his life and gave him a much-needed new perspective: that his past failures did not matter, they were not as important as his health and life itself. It also gave him the opportunity to discover his real passion, writing. He has been writing for more than two years now. It is through writing that he was able to get the self-respect, meaning, and fulfilment he had longed for. At present, Khue feels that he is ready for anything, and is no longer afraid of criticism, failure, or death. Khue hopes to publish a collection of short stories and a novel in the near future. 35

Dung's arrival in Canada in early 1981 also marked new beginnings in her life, albeit in a rather literal way. Upon arrival at the airport, Dung and other refugees were instructed to throw away their old clothes. They were then sprayed with disinfectant, told to wash their hair and to shower, and were given new clothes. The refugees were resettled according to their boat arrival period or number. The majority of those on Dung's boat were resettled in Calgary, which was then a booming city in need of workers. For Dung, the first few years in Calgary were tough. She found the weather punishing and the social landscape isolating. She experienced first-hand what it was like to be a member of a minority in terms of ethnic background and social class:

I used to work 10- to 12-hour days when I lived in Calgary. After work, I would catch the night bus home. I never really felt scared or alone on those trips, because there were also many workers on the bus, who were mostly from immigrant backgrounds like myself. Once, there were a few white people on the bus who stared rudely at me. One of them then spat at me. I was shocked and didn't do anything. Then, a few passengers, who looked Inuit to me, told me not to worry and not to think too much about the incident, that this happened to them on a regular basis. It was then that I realized that those white passengers had mistaken me for an Inuit or aboriginal. That was my first encounter with racial discrimination. ${ }^{36}$

After moving to Ottawa, Dung worked as a social worker for a few years, focusing on improving the mental health of refugees and other victims of trauma. She then worked for immigrant services at the City of Ottawa. Her job was to help create a new advocacy program for refugee women. During this period, she also studied part-time for a master's degree in social work. Dung then worked as a case 
coordinator for social services at the City of Ottawa until her retirement a few years ago.

Chi and Mai arrived in Toronto in January 1982, joining their elder brother and uncle in Toronto. The following year, the Le siblings moved to Ottawa, so that their brother could study computer engineering at the University of Ottawa. The sisters recalled the small and crammed space they had to share for the next few years. In the one-bedroom apartment, the four siblings shared the same sleeping space and a cardboard box served as both a dining and study table. It was Mai who adapted the most easily and most quickly, because she was the youngest. Her elder brother and Chi became surrogate parents-often clashing with Mai. Power struggles dominated their relationship. They frequently wrote letters to their mother in Vietnam, taking care to highlight that they were doing well and studying hard because they did not want her to worry. Likewise, their mother never mentioned anything that was not positive in her correspondence. Both sides were struggling in their own way but never let the other know. The Le siblings studied hard and took ESL, all of them graduating with computerrelated degrees.

The siblings managed to pool together their earnings to sponsor their remaining family in Vietnam, and their mother eventually joined them in 1992, along with three younger siblings and grandmother. They also saved enough money to buy a house for the family. Their father would join them in January 1995. He had aged much since they last saw him twenty years previously. Mai recalled how their family members walked on egg shells for the next few years. After their father went to re-education camp, their mother became the new head of the family and made all the decisions. Their father found it hard to adapt to and accept the changed family dynamics. 37

\section{The Ties That Never End: Vietnam}

There are those who have gone back and those who have not. While some reject any form of engagement with Vietnam, many are optimistic that continued socio-economic growth will lead to positive political changes. Some returned to Vietnam to renew kinship and social ties. Nhung returned to Vietnam twice, in 1997 and 2006. During her first trip, she visited her former hometown in Danang and the mountain where she used to teach, describing the reunion with relatives, childhood friends, former colleagues, and students as heart-warming and moving. It was also during those trips that she was able to make peace with her past and to gain clarity about where her home and belonging were now: "I saw how much Vietnam had changed. I had changed much too. Danang was too crowded for my likingVietnam's population has doubled since I left. Going back to
Vietnam made me realize, more than ever, that my home is in Canada." 38

Nhung feels that although Vietnam has changed and is now more developed than it was in the 1970s, she still feels that the country could have done much better. She recalled how during the 1960s, South Korean officials had come to Saigon on study missions to learn how to build a modern and developed city. South Korea grew by leaps and bounds in the 1990 s and early 2000 . The problem with Vietnam, in her opinion, was the lack of good leadership and management. However, many of the country's "best and the brightest" fled the country in the 1970s. Even now, many bright and promising Vietnamese are still leaving the countryand it is this very demographic the country needs to further modernize its economy.

Like Nhung, Phuong has also made peace with his past. He related how he used to take part in anti-communist protests when he first arrived in Canada and was actively involved with the Vietnamese community in Ottawa. Then in 1995 there were two milestones in his life. After the breakdown of his marriage, he went to live in Paris for two years and became a monk there. Through meditation, Phuong said he was able to attain a spiritual awakening and inner peace; he no longer blamed the communists for what happened in Vietnam and in his personal life. During his time in Paris, he came across documents that gave him new perspectives about the war, and he was able to have a more holistic view of Vietnamese political history:

By the early 1970s, the us had already decided to pull out of Vietnam, and made arrangements with the Soviet Union. Vietnam was, in a sense, caught in the middle, after the us left Vietnam to Russia. When I came to this understanding, my grudges against Vietnam melted away ... that was how the communists came to control the whole country. Communism as a political ideology was originally intended as a tool to get rid of colonialism. It was a violent tool to achieve a specific goal ... but it did the job.

I don't want the Vietnamese people to be divided anymore. The communists succeeded in unifying the country, unlike the other political forces or earlier nationalist groups, and I give them credit for that. Vietnam has done much better, progressed significantly from what it was during the 1960s and 1970s. Even though it is far from perfect, and many things could improve, it is still moving ahead. That is much better than chaos or total anarchy. It is easy to stay on the outside and criticize, but all this hatred is not effective in changing the country. The critics have been extremely vocal about the regime and the current state of affairs but have not offered any viable solution. 39

Phuong's new views about Vietnam brought him inner peace and acceptance of his past, but have also estranged 
him from the Vietnamese community in Ottawa. He was asked to leave the Vietnamese Canadian Federation when he started to express views that were not sufficiently anticommunist. His opinions, along with his pro-engagement stance, made him a "communist sympathizer" in the eyes of the Vietnamese community in Ottawa.

Phuong has returned to visit Vietnam twice, in 2001 and 2010. Each time he has been back, he feels that the country changed much; he could not recognize his old hometown in Danang, which had become a booming city: "Each time I have been back, I realize that Vietnamese people are still the same. We are essentially emotional and sentimental people, and that has not changed over time. I felt at home the first time I went back-I spoke the same language, and was able to connect with the people, instinctively. Even though I have changed much since I've lived in Canada, these changes were on the 'outer layer of consciousness' (e.g., education, work). The inner layer was still essentially Vietnamese. That is my cultural identity, and spiritual self."40

During his returns, Phuong managed to produce a traditional music CD that is sold in major bookshops in Vietnam. He also has plans to help develop solar panels for houses in the countryside. Like Phuong, Dung has returned to Vietnam several times. A few years ago, she helped set up a school for autistic children in Ho Chi Minh City. In late 2014, she raised enough funds to enable teachers from Vietnam to attend an educators conference on autism in Montreal. ${ }^{41}$

Those who choose not to go back do so out of fear and uncertainty, and in the case of Khue, as a matter of principle. He has not been back since he left the country and said that he will do so only when the country is "free" (from communist rule) and in the hands of the people. Although he does not condemn those who choose to return, he resents those who go back to Vietnam to show off their wealth and act as if they are better than the locals. These people, he felt, were betraying the soul of the country. Khue felt that there was still much poverty and hardship in the country, and he could not bear to witness the conspicuous gap between the rich and poor. It would break his heart to see that. "Vietnam will always have a special place in my heart. There is an inherent passion to live and die where your parents were born, where you were born ... that's where my life journey began. When I pass on, I would like to have my ashes scattered in my former hometown." 42

Khue felt that Vietnamese have an inherent connection to their ancestral homeland, although such sentiments are complex and multi-faceted. Differences in political viewpoints can be divisive and sometimes contentious within overseas Vietnamese communities. Khue related a recent encounter at a community event in Toronto, where he was approached by volunteers to sign a petition in support of Bill
S-219, also known as the Journey to Freedom Act. 43 Khue declined to give his support. His logic was that there were over a million overseas Vietnamese who returned yearly to Vietnam to tour and visit family, for business or philanthropy. These people were also returning in search their own "freedoms." He did not see the point of this bill, viewing it as moot and somewhat hypocritical. Khue's refusal to support the bill was greeted with shock and resentment by the community. Some accused him of being a communist sympathizer, a charge that Khue vehemently resented. To his detractors, he emphasized that he was "10o per cent boat person" who was against the communist regime and would not return until his country was "free." 44 Khue's and Phuong's narratives highlight the diversity and complexity of relations between Vietnamese and their former homeland.

\section{Conclusion}

These narratives illuminate the different paths that brought Vietnamese refugees to Canada. Each story highlights the profound dilemmas, motivations, and experiences of Vietnamese refugees. Collectively, these stories demonstrate the remarkable resilience of this community, and their determination to survive and remake themselves in their adopted country, Canada. The narratives also highlight the differing politics - of community engagement, attitudes of return and non-return-among my respondents. These differences reflect the diversity and disparity in attitudes and behaviour within the wider Vietnamese community in Canada.

Through the lenses provided by the experiences of the six respondents, the discussion has shown not only how this segment of the diaspora has dynamic and complex relations with the ancestral homeland, but also how such relations are continually evolving. The narratives demonstrate how my respondents continue to connect with "cultural" Vietnam, despite their distaste for and disengagement from "political" Vietnam. They also reveal the diverse and multi-faceted ways in which this segment of Vietnamese Canadians conceptualize home and belonging.

There is a growing acknowledgment about the fluid and dynamic relations diasporic peoples have with home and homeland. 45 Home is the space where they currently reside, the place where their immediate family lives, the country of parental origins, and/or where other family members live. Being-at-home therefore involves the coexistence of these three registers of home, although each has very different-and fluctuating-meanings. ${ }^{46}$ It is therefore possible for trans-migrants and displaced peoples to have more than one home and to feel at home in more than one place or space. Seen in this manner, my respondents' current ties to and engagement with Vietnam can be construed as a microcosm of contemporary trans-migrants' multiple allegiances, 
senses of belonging, homes, homelands, identities, and belongings-which are marked by diversity and complexity and are continually evolving and never complete. In so doing, the research aims to provoke further work in the burgeoning and vital field of oral history, which will provide deeper and more concrete understanding of questions concerning ethnic affiliation, notions of belonging, and diasporic ties with the homeland.

Forty years after that war, Vietnamese in Canada are refugees no more, but an intrinsic part of Canadian society and the country's immigration history. These narratives reveal that for these former refugees, home is where they are now and where they see their futures. At the same time, Vietnam continues to hold a special place their hearts and minds. In this deeply personal and sentimental space lies a collection of things past, present, and still to come.

\section{Notes}

1 Caroline Vu, Palawan Story (Aylmer, QC: Deux Voiliers Publishing, 2014), 155.

2 See, for instance, Andrew Pham, Catfish and Mandala: A Two-Wheeled Voyage through the Landscape and Memory of Vietnam (New York: Farrar, Straus and Giroux, 1999); Thuy Diem Thi Le, The Gangster We Are All Looking For (New York: Alfred A. Knopf, 2003); Andrew Lam, Perfume Dreams: Reflections of the Vietnamese Diaspora (Berkeley, CA: Heyday Books, 2005); Journey from the Fall, dir. Tran Ham (Santa Monica: ImaginAsian Home Entertainment, 2006); Nam Le, The Boat (New York: Alfred A. Knopf, 2008); Kim Thuy, Ru (Montreal: Vintage Canada, 2009).

3 Interviews with the sixth respondent, who is based in Toronto, were conducted via phone.

4 It is imperative to remember what life history and narrative analysis remind us of about how people make sense of their life stories. When a person tells his or her life story, the information has been edited and events selected to create a story that is compatible with the present. Therefore, my respondents were not simply recalling facts, but also interpreting the past in the light of the present. See John Clausen, "Life Reviews and Life Stories," in Methods of Life Course Research: Qualitative and Quantitative Approaches, ed. Janet Z. Giele and Glen H. Elder Jr., 189-212 (Thousand Oaks, CA: Sage, 1998); Ruthellen Josselson and Aima Lieblich Aima, eds., Interpreting Experience: The Narrative Study of Lives (Thousand Oaks, CA: Sage, 1995).

5 During this period, the regime nationalized businesses and industries, collectivized agriculture, imposed currency reform, and confiscated private property wholesale. Chinese businesses and schools were closed in 1976, and Chinese-Vietnamese had to register their citizenship. Family members of former military personnel and administrative staff of the former South Vietnamese government were discriminated against in education and employment, as were the Chinese and Amerasians. See W. Courtland Robinson, Terms of Refuge: The Indochinese Exodus and the International Response (London: Zed Books, 1998); Robert S. McKelvey, Dust of Life: America's Children Abandoned in Vietnam (Seattle: University of Washington Press, 1998).

6 See Judith Banister, “The Population of Vietnam," International Population Reports, series P-95, no. 77 (Washington, DC: Us Bureau of the Census, 1985); Judith Banister, "Vietnam: Population Dynamics and Prospects," Indochina Research Monograph, no. 6 (Berkeley: Institute of East Asian Studies, University of California-Berkeley, 1993).

7 Initiated in 1979, the oDp that was intended to facilitate the departure of those who were associated with the former South Vietnamese government and military, and who had been subjected to years of imprisonment and systematic discrimination.

8 The 1988 Amerasian Homecoming Act and the 1989 Humanitarian Operation Program further led to the exit and resettlement of children fathered by American military personnel and the remaining former South Vietnamese prisoners respectively. See Paul Rutledge, The Vietnamese Experience in America (Bloomington: Indiana University Press, 1992); James Freeman, Changing Identities: Vietnamese Americans, 1975-1995 (Boston: Allyn and Bacon, 1995); Sucheng Chan, The Vietnamese American 1.5 Generation: Stories of War, Revolution, Flight and New Beginnings (Philadelphia: Temple University Press,2006).

9 Yen Le Espiritu and Tran Thơm, "Việt Nam, Nước Tôi: Vietnamese Americans and Transnationalism," in The Changing Face of Home: The Transnational Lives of the Second Generation, ed. Peggy Levitt and Mary C. Waters, 395 (New York: Russell Sage Foundation, 2002).

10 Robinson, Terms of Refuge, 127.

11 Following the French defeat at Dien Bien Phu, the country was partitioned into North and South Vietnam, in accordance with the Geneva Accords of 1954. The North would be governed by the communist forces, and the US backed non-communists in the South.

12 Dung, personal interview, Ottawa, 28 October 2014.

13 Phuong, personal interview, Ottawa, 25 October 2014.

14 Chi, personal Interview. Ottawa, 13 January 2015.

15 Mai, personal interview, Ottawa, 3 March 2015.

16 Nhung, personal interview, Ottawa, 17 October 2014.

17 Nhung, personal interview, Ottawa, 25 November 2014.

18 Dung, personal interview.

19 Chi, personal interview.

20 The young boatman would take wood from the boat structure, and chop it up to cook food on the island. He also did not know which direction to steer the boat, so her brother and two of his friends took over the helm, relying on the compass they had brought with them.

21 Nhung, personal interview, Ottawa, 25 November 2014. 22 Chi, personal interview. 
23 Robinson, Terms of Refuge, 31.

24 Khue, phone interview, 2 April 2015. Between 1979 and 1980, Vietnam and China were embroiled in an intense military conflict along the Sino-Vietnamese border.

25 Phuong, personal interview.

26 Dung, personal interview.

27 Nhung, personal interview, Ottawa, 10 January 2015.

28 Mai and Chi, personal interview, 2 February 2015.

29 Phuong, personal interview.

30 Dung, personal interview, Ottawa, 5 November 2014.

31 "Boat-People': A Refugee Crisis-Vietnamese-Canadian History," Radio Canada International, http:// www.rcinet.ca/patrimoine-asiatique-en/le-mois-dupatrimoine-asiatique-au-canada/les-refugies-de-la-merla-communaute-vietnamienne/.

32 In 1979, Marion Dewar, mayor of Ottawa, created Project 4,00o to resettle 4,00o refugees from Vietnam, Cambodia, and Laos in Ottawa through private sponsorship. Nhung was a beneficiary of this project.

33 Nhung, personal interview, 10 January 2015.

34 Ibid.

35 Khue, phone interview.

36 Dung, personal interview, Ottawa, 5 November 2014.

37 Mai, personal interview, Ottawa, 3 March 2015.
38 Nhung, ersonal interview, 10 January 2015.

39 Phuong, personal interview.

40 Ibid.

41 Dung, personal interview, 5 November 2014.

42 Khue, phone interview.

43 The bills seeks recognition of 30 April as a national day to commemorate the exodus of Vietnamese refugees and their acceptance in Canada after the fall of Saigon to North Vietnamese communist forces.

44 Khue, phone interview.

45 See Dorinne Kondo, "The Narrative Production of 'Home,' Community and Identity in Asian American Theatre," in Dislocation, Diaspora and Geographies of Identity, ed. Smadar Lavie and Ted Swedenburg, 97-118 (Durham, NC: Duke University Press, 1996); Alison Blunt and Robyn Dowling, Home: Key Ideas in Geography (London: Routledge, 2006).

46 Sara Ahmad, "Home and Away: Narratives of Migration and Estrangement," International Journal of Cultural Studies 2, no. 3 (1999): 329-47.

Priscilla Koh is an independent scholar based in Singapore. She may be reached at priskoh76@yahoo.com. 